\title{
Ni-Ti Alloys Produced by Powder Metallurgy
}

Pavel Salvetr, Pavel Novák, Hynek Moravec

University of Chemistry and Technology, Department of Metals and Corrosion Engineering, Technicka 5, 16628 Prague

6, Czech Republic

Email: psalvetr@seznam.cz, Paja.Novak@vscht.cz, Hynek.Moravec@vscht.cz

This paper deals with the influence of alloying elements on the properties of Ni-Ti alloys. The base alloy was the binary alloy Ni-Ti with 54 wt. \% $\mathrm{Ni}$ and $46 \mathrm{wt}$. \% Ti. Alloying elements (aluminium, iron and vanadium) in an amount of $5 \mathrm{wt}$. \% were added to this alloy. All samples have been prepared by the method of powder metallurgy - reactive sintering at $1100{ }^{\circ} \mathrm{C}$ for 20 minutes. Microstructure, phase composition (especially amount of the $\mathrm{Ti}_{2} \mathrm{Ni}$ phase), process of sintering and the formation temperature of intermetallic phase NiTi, transformation temperatures and mechanical properties have been examined in these alloys. The corrosion characteristics were measured on the Ni-Ti and NiTiV5 alloys.

Keywords: Ni-Ti, powder metallurgy, reactive sintering.

\section{Acknowledgement}

This research was financially supported by Czech Science Foundation, project No. 14-03044S.

\section{References}

[1] K. OTSUKA, X. REN (2005). Physical metallurgy of Ti-Ni-based shape memory alloys, Progress in Materials Science, 50, 511-678.

[2] P. NOVÁK, A. ŠKOLÁKOVÁ, V. VOJTĚCH, A. KNAISLOVÁ, P. POKORNÝ, H. MORAVEC, J. KOPEČEK, M. KARLÍK, T. KUBATÍK. (2014). Application of Microscopy and X-ray Diffraction in Optimization of the Production of NiTi Alloy by Powder Metallurgy, Manufacturing Technology, 14. 387 - 392.

[3] Y. KAIEDA. (2003). Fabrication of composition-controlled TiNi shape memory wire using combustion synthesis process and the influence of $\mathrm{Ni}$ content on phase transformation behavior, Science and Technology of Advanced Materials, 4, 239-246.

[4] T. DUERIG, A. PELTON, C. TREPANIER. (2001). Nitinol, PART I Mechanisms and Behavior, SMST E-lastic newsletter.

[5] A.S. JABUR, J.T. AL-HAIDARY, E.S. AL-HASANI. (2013). Characterization of Ni-Ti shape memory alloys prepared by powder metallurgy, Journal of Alloys and Compounds, 578. 136-142.

[6] J. FRENZEL, Z. ZHANG, K. NEUKING, G. EGGELER (2004). High quality vacuum induction melting of small quantities of NiTi shape memory alloys in graphite crucibles, Journal of Alloys and Compounds, 385. 214-223.

[7] N. NAYAN, GOVIND, C.N. SAIKRISHNA, K.V. RAMAIAH, S.K. BHAUMIK, K.S. NAIR, M.C. (2007). Mittal, Vacuum induction melting of NiTi shape memory alloys in graphite crucible, Materials Science and Engineering: A, 465. 44-48.

[8] L.M. SCHETKY, M.H. WU. (2003). Issues in the Further Development of Nitinol Properties And Processing for Medical Device Applications, in: ASM Materials \& Processes for Medical Devices Conference, Anaheim, pp. 271.

[9] M.H. WU. (2001). Fabrication of Nitinol Materials and Components, in: Proceedings of the International Conference on Shape Memory and Superelastic Technologies, Kunming, China, pp. 285-292.

[10] V. KUČERA, J. ČAPEK, A. MICHALCOVÁ, D. VOJTĚCH (2014). Preparation and Characterization of NiTi Shape Memory Alloy Prepared by Powder Metallurgy, Manufacturing Technology, 14. 342-347.

[11]P. NOVÁK, A. MICHALCOVÁ, I. MAREK, M. VODĚROVÁ, D. VOJTĚCH (2012). Possibilities of the observation of chemical reactions during the preparation of intermetallics by reactive sintering, Manufacturing Technology, 12. $197-201$.

[12]M. KAYA, N. ORHAN, B. KURT, T.I. KHAN. (2009). The effect of solution treatment under loading on the microstructure and phase transformation behavior of porous NiTi shape memory alloy fabricated by SHS, Journal of Alloys and Compounds, 475. 378-382. 
[13]P. NOVÁK, L. MEJZLÍKOVÁ, A. MICHALCOVÁ, J. ČAPEK, P. BERAN, D. VOJTĚCH. (2013). Effect of SHS conditions on microstructure of NiTi shape memory alloy, Intermetallics, 42. 85-91.

[14]P. NOVÁK, P. POKORNÝ, V. VOJTĚCH, A. KNAISLOVÁ, A. ŠKOLÁKOVÁ, J. ČAPEK, M. KARLÍK, J. KOPEČEK. (2015). Formation of Ni-Ti intermetallics during reactive sintering at $500-650{ }^{\circ} \mathrm{C}$, Materials Chemistry and Physics, 155. 113-121.

[15]M. BRAM, A. AHMAD-KHANLOU, A. HECKMANN, B. FUCHS, H.P. BUCHKREMER, D. STÖVER. (2002). Powder metallurgical fabrication processes for NiTi shape memory alloy parts, Materials Science and Engineering: A, 337. 254-263.

[16]M.H. ELAHINIA, M. HASHEMI, M. TABESH, S.B. BHADURI. (2012). Manufacturing and processing of NiTi implants: A review, Progress in Materials Science, 57. 911-946.

Paper number: M2015124

Copyright $\odot$ 2015. Published by Manufacturing Technology. All rights reserved. 